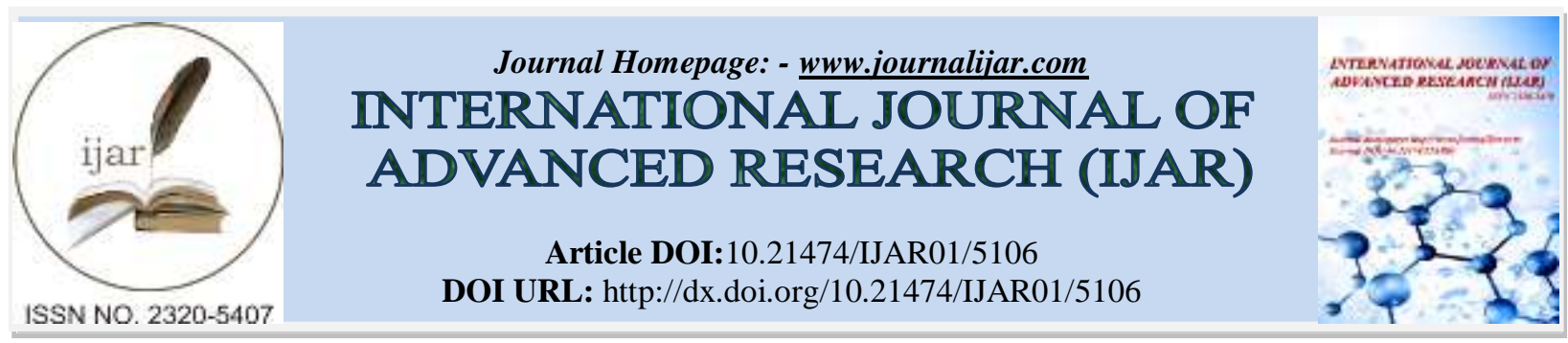

RESEARCH ARTICLE

\title{
PAULO COELHO'S ALEPH- AN EXPLORATION OF HINDU PHILOSOPHY.
}

Mr. Shrinivas Yedle.

M. A. English, NET.

\section{Manuscript Info}

\section{Manuscript History}

Received: 08 June 2017

Final Accepted: 10 July 2017

Published: August 2017

Key words:-

Hindu Philosophy, liberation, karma theory, salvation.

\begin{abstract}
Paulo Coelho is a Brazilian writer and lyricist. He has written many novels and translated in many languages all over the world. Aleph is a spiritual autobiography of Paulo Coelho in which he describes his experiences in the form of Novel. In the story the two characters meets each other after 500 years. The crisis in faith in God makes the narrator to initiate the journey from Asia to Europe; in the journey he meets the other character Hilal who is also facing the same problem. The Present paper finds out the aspects of Hindu philosophy reflected in the Novel. Hindu philosophy is divided in six schools- Samkhya, Nyaya, Yoga, Vedanta, Vaishesika and Mimnsa. These schools have some ethical differences in them. But all accept the concepts of God, liberation, karma theory and salvation. The present paper only deals with these concepts reflected in the novel. For the paper assumed that "Aleph" is a novel and for the study the researcher use analytical method.
\end{abstract}

Copy Right, IJAR, 2017,. All rights reserved.

\section{Introduction:-}

Paulo Coelho de Souza (born august 24, 1947) is a Brazilian lyricist and novelist and the recipient of numerous international awards. He is best known for his novel the alchemist, which became one of the best-selling books in history, and has been translated into 81 different languages, winning the Guinness world record for most translated book by a living author. Till today he published 30 books in which the three- the Pilgrimage, the Valkyries and Aleph- are autobiographical.

Aleph is a novel by Paulo Coelho published in 2011. It is one of the best books by Coelho, and touches on the theme of spirituality. Aleph was written in Coelho's native language, Portuguese. The novel is a spiritual autobiography of Coelho in which Coelho himself is a narrator but after the publication, it is become the best seller novel that translated in many languages.

Hindu religion is one of the oldest religions in the world which based on its own philosophy which known as Hindu philosophy. Hindu philosophy is a group of philosophical schools those emerged in ancient India. The main stream ancient schools of philosophy were samkhya, yoga, nyaya, vaisheshika, mimnsa and vedanta. These are called astika philosophy and accept "Vedas" as important source of knowledge. These schools flows on the basis of Vedic authority these schools have some debates over some concepts but all schools have some basic/prominent concepts those are discussed in the paper. They are existence of god, karma sidhanta (karma theory), punarjanam (reincarnation), moksha (liberation). The present paper finds out the aspects of Hindu philosophy reflected in the novel 'Aleph'. For the paper the researcher assumed that "Aleph" is a novel by Paulo Coelho. 


\section{Objective of the paper:-}

To study the Hindu philosophy reflected in the novel.

Hindu philosophy believes in the existence of god or in the principal of theism. The god is the director of the universe. This principal is used in the novel.

The novel revolves around the existence of god. The main characters of the novel believe in the existence of god.

In the novel Paulo is facing a grave crisis of faith, and seeking a path of spiritual renewal and growth. He decides to start over: to travel, to experiment and to reconnect with people and the world. Setting off to Africa, and then to Europe and Asia via the trans-Siberian railway, he initiates a journey to revitalize his energy and passion. Even so, he never expects to meet Hilal. A gifted young violinist, she is the woman he betrayed in an act of cowardice so far reaching that it prevents him from finding real happiness in this life. Together they will initiate a mystical voyage through time and space, travelling a path that teaches love, forgiveness and the courage to overcome life's inevitable challenges. When the narrator firstly saw in the eyes of Hilal, he felt something spiritual, from that moment the narrator attracted towards her.

The Hindu philosophy believes in the principal of rebirth or reincarnation.

$$
\begin{aligned}
& \text { वासांसि जीर्णानि यथा विहाय नवानि गृहरणाति नरोऽपराणि। } \\
& \text { तथा शरीराणि विहायजीर्णान्यन्यानि संयाति नवानि देही।। } \\
& \text { Vāsānsi jīrnāni yathā vihāya navāni grihnāti naro.aparāni. } \\
& \text { Tathā śarīrāni vihāyajīrnānyanyāni sanyāti navāni dehī.. }
\end{aligned}
$$

This verse refers to the doctrine of reincarnation in Hinduism. Death is described here as the simple discarding of a worn-out garment for a new one. When the body becomes diseased and old, the ever-lasting soul forsakes it for a new disguise. Death is but a change of attire in an uninterrupted continuity of immortality.

During our daily lives we change our old and/or dirty clothes and put on new and/or clean clothes whenever the need arises. Similarly, the soul or atman casts off its worn out physical body and takes residence in a newer physical body at regular intervals in time.

Just like the clothes that we wear do not represent the real state of our physical body, the state of our physical body (which deteriorates over time and is hence impermanent) does not represent the truly unchangeable and permanent nature of the soul that resides within it.

The eternal does not move from place to place but the embodied soul moves from one abode to another. It takes birth each time and gathers to itself a mind, life and body formed out of the materials of nature according to its past evolution and its needs for the future. The psychic being is the vijnana which supports the triple manifestation of body, life and mind. When the gross physical body falls away, the vital and mental sheaths still remain as the vehicle of the soul. Rebirth is the law of nature. There is an objective connection between the various forms of life.

This principal is used in the novel everywhere because it is the story of Coelho and Hilal.

In the novel the narrator meets Hilal - the women he loved 500 years before. Both meet in trans-Siberian railway journey. In the 500 years before they were together having different names. This journey was very useful to the author because it gave him the possibility to return back to his past and ask forgiveness from Hilal, and it was useful to Hilal too, because she became more tolerant with others and with herself and she decides to continue her life with optimism. Coelho wrote, "The moments that precede sleep are very similar to death. We are filled by torpor and it is impossible to know when the "i" takes on different form. Ours dreams are our second life. I am incapable of going through the doors that lead us to that invisible world without a shiver." P.271.

The story is the binding of past, present and future in one place and point that named in the novel aleph.

In the novel the J. Says, "Our life is a constant journey, from birth to death. The landscape changes, the people change, but the train keeps moving. Life is the train, not the station...." P 11. 
Hilal in the story mentioned that her journey with the narrator is the journey for salvation. Here salvation means the regaining the faith in god.

The other main principal of Hindu philosophy is the karma sidhanth. A common thesis associated with Hinduism is the view that events in a person's life are determined by karma of the present life of the individual. The karmas are the causes of the nature, character, tendencies, and physique, social and economic conditions. The term literally means "action," but in this context it denotes the moral, psychological spiritual and physical causal consequences of morally significant past choices. Karma means good deeds that decide your future, next birth. If your karmas are good and ideal, you will get liberation (moksha) from the cycle of life and death. Good karmas bring happiness in one's life where as bad acts bring sufferings in one's life. It is this tendency or samskara or vasana that inclines us to repeat the deed we have once done. So, all deeds have their fruits in the world and effects on the mind. In the novel J. explains the theory of karma as, "in India they use the word "karma" for lack of any better term." The wrong act done by the narrator in the first life, before 500 year, now he is requesting Hilal for forgiveness for that act. This story of the novel itself is the example of karma theory. Every birth has some the real reason for their existence and out of the concept of hell and heaven is born. In the novel J. narrates an example of a murder. Crime was not the responsibility of the murderer, but of all those who created the condition in which the crime could occur. The theory also guides us to work without thinking of its fruits. Because the continuous works leads you towards the destination.

In Hindu philosophy guru has very important role in the life of disciples. There is a long list of guru - sishsya tradition. In the novel $\mathrm{j}$. Works as the guru of the narrator whose experiences and lessons made the narrator to think of. He explains the concept of life, death, eternity, liberation to the narrator, who also suggested him not to travel into the past.

The whole story of the novel is for salvation and redemption. The narrator is excused at the end of the novel by Hilal is one type of redemption.

The main aim of life, according to Hindu philosophy is mukti or moksha (liberation). Liberation means to get freedom from the birth and death circle. Mukti is the removal of bondage, perfect freedom and realization of Ishwara. It may be realized by devotion, yoga, celibacy, learning, simple living and high thinking and fulfillment of the purusarthas. In the novel the narrator and Hilal get freedom from their past sufferings (mistakes). This is one type of liberations or mukti.. Moksha or mukti is not discussed a lot in the novel but a character J. speaks philosophically on life, death, karma and liberation. Liberation can be achieved by good deeds and praying to god. In the novel Hilal and narrator pray for forgiveness in the church,

\title{
"I forgive the tears $i$ was made to shed
}

\author{
I forgive the world and all its evils." P.169
}

Such prayers are used in all religions.

\section{Conclusion:-}

Hindu philosophy is one of the oldest schools of the philosophy and it has gone through many changes. The story of the novel and the statements, made by the narrator and the other characters -Hilal, J. , Yao., are themselves philosophical which are closely associated with the Hindu philosophy. The story is elaboration of the concepts liberation, salvation, reincarnation and so on. Lastly, i would conclude my paper saying that "aleph" is an elaboration of Hindu philosophy. 


\section{References:-}

A. Primary source:

1. Coelho, Paulo. Aleph. London (UK) : the Harper Collins publishers,2011.

B. Secondary sources

1. Radhakrishnan S. Bhagavadgita. Delhi: Rajput and sons, 1962.

2. Hick,John H. Philosophy of Religion. (reprint. 12 $2^{\text {th }}$ ed.) New Delhi: Prentice Hall of India ltd.2003.

3. Dyaneswar, Maharaj. Gita: the Mother. Ludhiana: Kalyani Publishers, 1972.

4. Tattayanbhuhan, S. The Bhagavadgita. New Delhi: Cosmo Publication 1987.

5. Yoganda, Parmahansa. The Bhagavadgita Vol I. Vidyananda, 1992.

6. Chatterjee, Satishchandra and Dutta Dhirendra Mohan. An Introduction to Indian philosophy. New Delhi: Rupa Publication. 